\title{
In situ culturing of larvae of the crown-of-thorns starfish Acanthaster planci
}

\author{
Richard Randolph Olson
}

Australian Institute of Marine Science, P. M. B. 3, Townsville M. C., Queensland 4810, Australia

ABSTRACT: Larvae of the crown-of-thorns starfish Acanthaster planci were reared in situ at 5 and $15 \mathrm{~m}$ depths using submersible culture chambers. Larvae developed normally and most were at the mid brachiolaria stage after $12 \mathrm{~d}$. All larvae showed signs of feeding as evidenced by yellow and green coloration in their digestive tracts. In situ culturing of A. planci larvae is a feasible means of investigating the relevancy of laboratory diets to natural food levels.

The crown-of-thorns starfish, Acanthaster planci, continues to outbreak on the Great Barrier Reef (Endean 1982). Despite $20 \mathrm{yr}$ of research, it is still unknown whether most outbreaks arise from larval recruitment or mass migration of adults between isolated reefs (Moran et al. 1985). Lucas (1982) and Birkeland (1982) have hypothesized that the larvae of $A$. planci ordinarily suffer high levels of mortality due to starvation. Lucas, in raising $A$. planci larvae on single species diets of Dunalielia primolecta and Phaeodactylum tricornutum, found that at cell densities comparable to levels found in coral reef waters (comparing chlorophyll a content), larval development was slow, survivorship very low, and no larvae advanced to the point of competency to settle. Although the standing crop of phytoplankton, in terms of chlorophyll $a$, in waters of the Great Barrier Reef may be relatively low (Ikeda et al. 1980), the decreased biomass might be offset by nutritional benefits of a mixed diet of phytoplankters.

The relevance of laboratory growth studies of planktotrophic larvae to natural growth rates has seldom been investigated (Bayne 1976, Kinne 1977). Previous studies have noted that although natural levels of phytoplankton biomass are generally less than levels

Contribution No. 298 from The Australian Institute of Marine Science

(c) Inter-Research/Printed in F. R. Germany needed for maximal growth in laboratory cultures using single species of phytoplankton, there is probably a compensation due to the mixture of species encountered by a larva in nature (Walne 1963, Kinne 1977). The benefits of mixed species diets have been documented for bivalves (Davis \& Guillard 1958. Bayne 1965) and copepods (Gaudy 1974, Hag 1967).

Materials and methods. To test whether natural food levels are sufficient to support the early stages of development of Acanthaster planci, 2 submersible larval culture systems were constructed (Fig. 1). Each system contained 4 larval chambers, a bilge pump (Rule Co. Ltd, $800 \mathrm{gal} \mathrm{h}^{-1}$ ) to flush the chambers, a timing circuit to turn the pump on for $30 \mathrm{~s}$ every $15 \mathrm{~min}$, and changeable battery packs containing $12 \mathrm{~V}$ gel-cell batteries. The intake port of the pump had a $100 \mu \mathrm{m}$ mesh sieve which was changed every other day. The larval chambers were $150 \mathrm{ml}$ polystyrene jars with their bottoms replaced with $100 \mu \mathrm{m}$ mesh, and with a piece of $100 \mu \mathrm{m}$ mesh covering the top of the jar as it was screwed into its lid. The lid of the jar had nine 1 $\mathrm{cm}$ holes and was attached to a flow spreader which ensured an even flow into the chamber.

Eggs of Acanthaster planci were fertilized in the laboratory $2 \mathrm{~d}$ before deployment of the submersible culture systems. Gamete collection and fertilization were performed using the methods described by Lucas (1982), except that the sperm used had been kept at $10^{\circ} \mathrm{C}$ for $10 \mathrm{~d}$ prior to fertilization. Forty $2 \mathrm{~d}$ old bipinnaria larvae were placed into each culture chamber. The systems were placed at 5 and $15 \mathrm{~m}$ depths in the back-reef area of Centipede Reef, a mid-shelf reef on the Great Barrier Reef, Australia on January 22, 1985.

Every other day for $10 \mathrm{~d}$, the containers were removed from the 2 systems, placed into water-tight boxes underwater and taken to the laboratory. The 


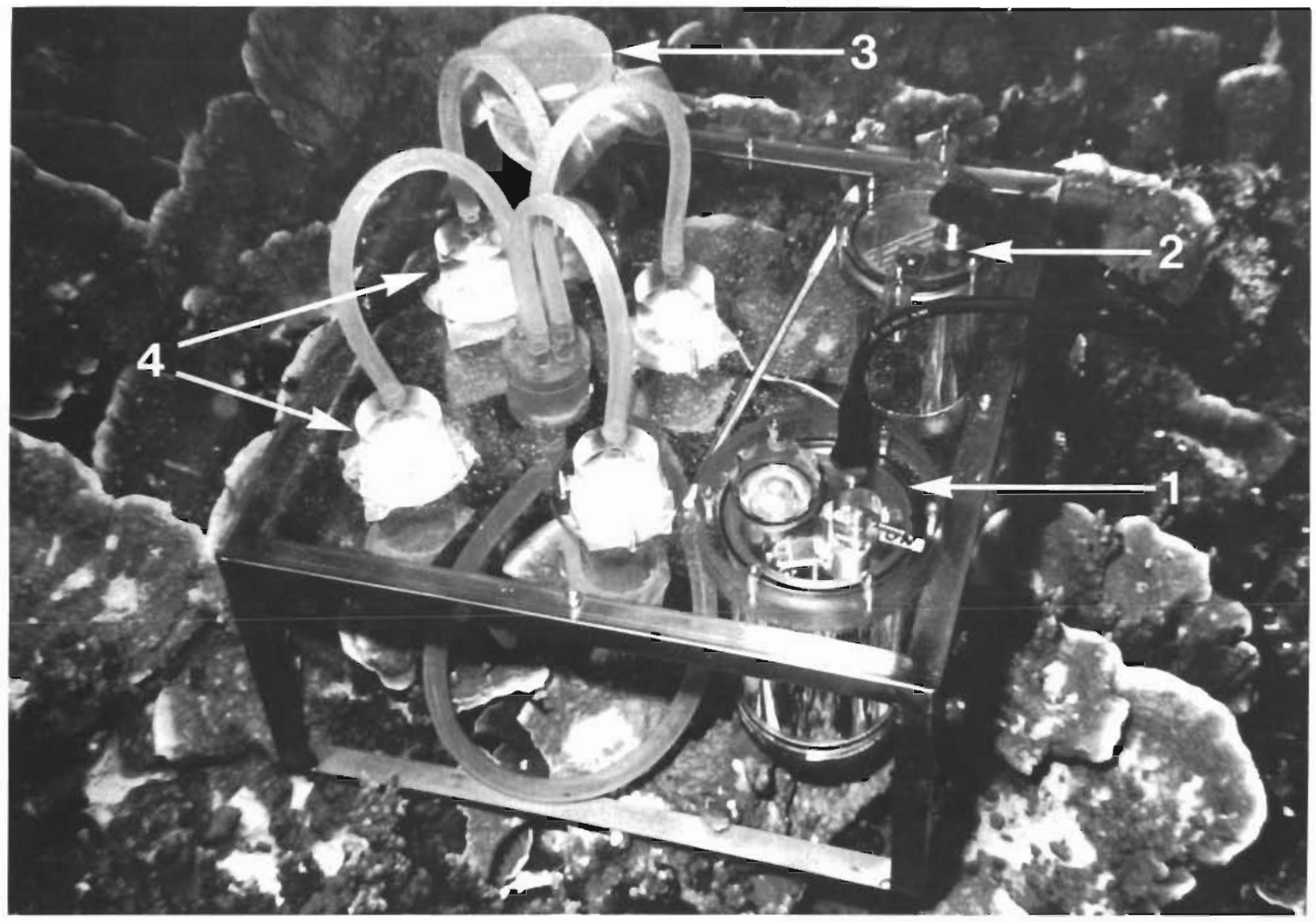

Fig. 1. Submersible larval culture system at $5 \mathrm{~m}$ depth on the back-reef of Centipede Reef, Australia. 1: $12 \mathrm{~V}$ changeable battery pack; 2: timing circuit; $3: 800 \mathrm{gal} \mathrm{h}^{-1}$ bilge pump; 4: larval incubation chambers

contents of each chamber were transferred into a beaker and the chamber was rinsed with $0.45 \mu \mathrm{m}$ Millepore filtered seawater (MFSW) to collect any remaining larvae. The larvae were examined with a dissecting microscope and developmental stages were recorded using the stages identified by Lucas (1982). After all larvae had been pipetted into MFSW they were poured into containers with clean mesh, then returned to the field. The whole process usually required about 3 h.

Results. For the first $5 \mathrm{~d}$ of the experiment the winds blew from the N. W. (the opposite direction to prevailing winds), bringing clear, offshore water into the back-reef. During this time the mesh on the chambers and the intake of the pumps remained white and only lightly fouled. Due to time constraints, only 1 chamber each from the shallow and deep systems was examined and changed. The mesh of containers not changed were heavily clogged by Day 6 (Fig. 2) and all larvae were dead. However, larvae in the chambers that were changed appeared healthy and active.

More than half of the larvae, which began the experiment as bipinnaria, had developed brachiolarial arms by the first examination, making them early brachiolaria (Fig, 2). Water temperature, which was measured when the chambers were collected, ranged between 28 and $29^{\circ} \mathrm{C}$ at both depths throughout the study

There was clear evidence of larval feeding from the first examination day (Day 4, Fig. 2). Larvae, especially in the shallow container, had bright yellow coloration in their alimentary canals. No coloration is usually seen in the gut of starved larvae (Lucas 1982). The coloration seen in the experimental larvae did not fill the entire stomach, but was only present at the anterior and posterior ends. Each spot of pigmentation was approximately one-fourth the size of the stomach. By the third examination day (Day 8 in Fig. 2) all larvae had coloration in their guts. Larvae at the $15 \mathrm{~m}$ site had dark brown coloration in addition to the bright yellow.

The rates of development of the 2 groups (Fig. 2) show that conditions were not as favourable as the optimal conditions found in laboratory culturing of Acanthaster planci (see Fig 4 in Lucas 1982). However, the larvae clearly were not suffering starvation. One larva in the shallow container had a fully 
Fig. 2. Stages of larval development (described in Lucas 1982) versus days since fertilization for cultures at 5 and $15 \mathrm{~m}$ depths
SHALLOW $(5 \mathrm{~m})$
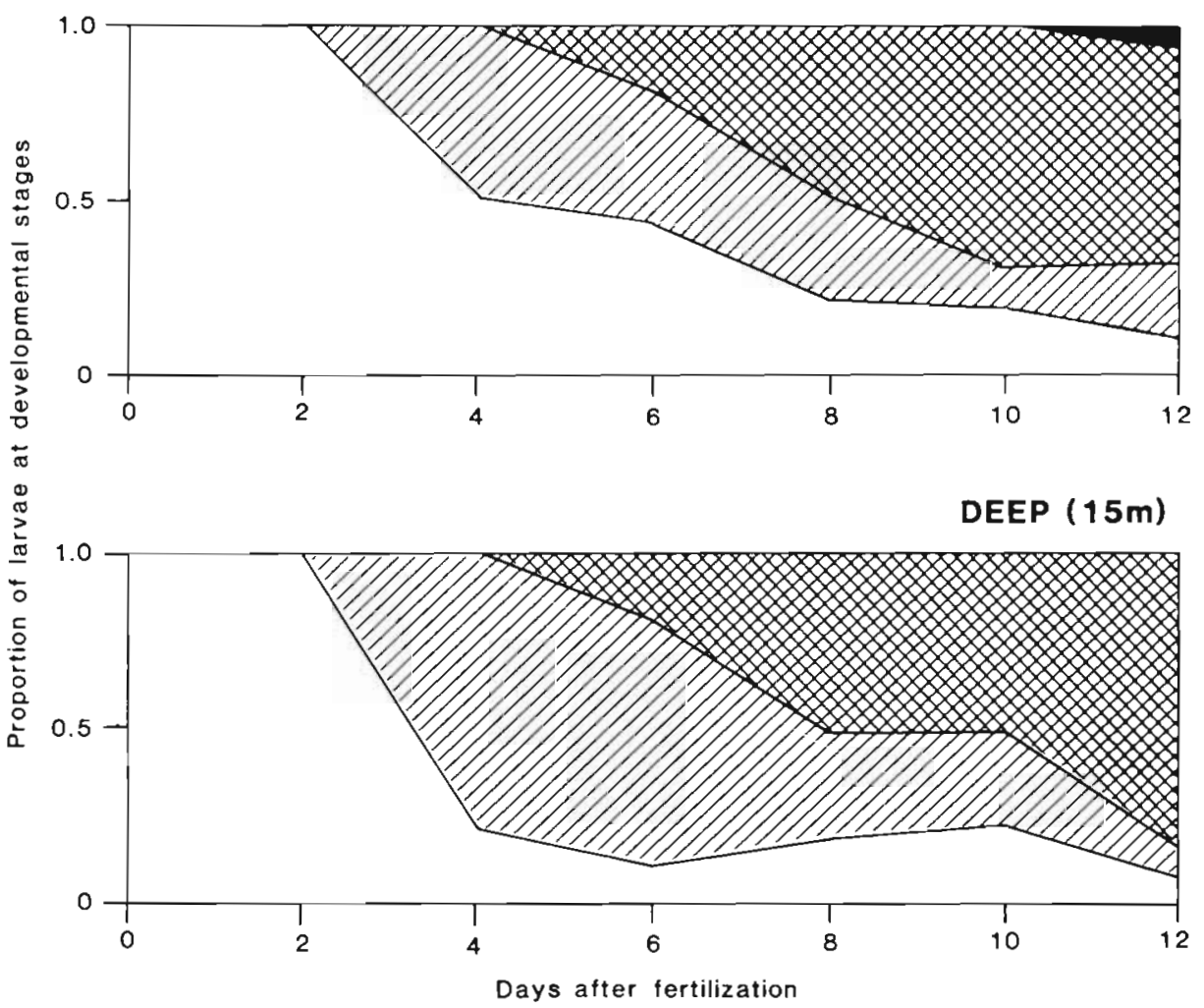

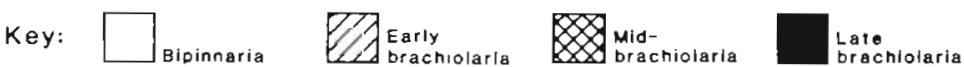

developed primordium and long thin arms, indicating it was nearly competent to settle. Many others had developed a region of bright yellow pigmentation where the primordium appears, but they had not begun to enlarge in that region.

When examined underwater, the larvae were swimming always at the very top of the container. The same behaviour is seen in the laboratory; larvae swim up to the surface except at the late brachiolaria stage when they become negatively buoyant and crawl on the bottom of the containers (J. Lucas pers. comm., author's own obs.). This crawling behaviour was seen in the larva in the shallow container which attained late brachiolaria stage.

Discussion. An important question regarding the submersible larval chambers is whether they might retain phytoplankton, resulting in the larvae encountering higher than normal cell densities. The flow through the chambers was visualized by releasing fluorescein dye at the intake of the pump. Even in chambers which had been running in the field for $2 \mathrm{~d}$, the dye flowed evenly through the chambers and was rapidly expelled. No major eddies were observed suggesting that larvae would not have encountered abnor- mal concentrations of plant cells. During a $30 \mathrm{~s}$ flush, 9.41 of seawater is pumped through each chamber. To test whether the chambers retain phytoplankton, the system was run for $2 \mathrm{~d}$ in a $1 \mathrm{~m}$ deep tank with flowing seawater in full sunlight. Phytoplankton levels (in terms of chlorophyll a) within the chambers were not significantly different from the ambient seawater after 2 d (Table 1).

Another important consideration is what the ideal flushing rate might be. I chose to have the pumps flush. every $15 \mathrm{~min}$ for the following reasons. According to Lucas (1982), larvae of Acanthaster planci process a

Table 1. A test for retention of phytoplankton in larval culture chambers. Data are $\mu \mathrm{g}$ chl a $\mathrm{l}^{-1}$. Values in parentheses are standard deviations. $\mathrm{N}=4$ samples for each mean.

\begin{tabular}{|lccccc|}
\hline & \multicolumn{2}{c}{ Day 1 } & \multicolumn{2}{c|}{ Day 2 } \\
\hline Within chamber & 0.162 & $(0.038)$ & 0.147 & $(0.017)$ \\
A.mbient seawater & 0.184 & $(0.011)$ & 0.151 & $(0.008)$ \\
t-test & NS & $(\mathrm{p}>0.1)$ & NS & $(\mathrm{p}>0.1)$ \\
NS Not significant & & & & \\
\hline
\end{tabular}


maximum of about $400 \mu \mathrm{l}$ of seawater larva ${ }^{-1} \mathrm{~h}^{-1}$. Each chamber held 40 larvae, so the larvae processed $16 \mathrm{ml}$ of seawater $h^{-1}$. The chamber volume was $150 \mathrm{ml}$. By flushing every $15 \mathrm{~min}$, no more than $10 \%$ of the water in the chamber was ever processed by the larvae. Also, oxygen consumption by 40 larvae in 15 min was negligible. Assuming the seawater to have been oxygen saturated, each chamber contained approximately 0.7 $\mathrm{ml}$ of dissolved oxygen $\left(0.15 \mathrm{l} \times 4.5 \mathrm{ml} \mathrm{O}_{2} 1^{-1}\right)$. Using a value for oxygen consumption by larvae of the echinoid Strongylocentrotus purpuratus of $3.5 \times 10^{-7}$ $\mathrm{ml} \mathrm{O}$ larva $^{-1} \mathrm{~h}^{-1}$ (Scholander et al. 1952), the $A$. planci larvae consumed approximately $1.4 \times 10^{-5} \mathrm{ml}$ $\mathrm{O}_{2}$ during 15 min, which is less than $1 \%$ of the dissolved oxygen in the chamber.

Although survivorship was not very high (23 of 40 for $5 \mathrm{~m}$ depth, 16 of 40 for $15 \mathrm{~m}$ depth), most of the loss is believed to be due to errors in handling of the chambers. The larvae that survived appeared healthy, active, and showed little or no signs of dedifferentiation (a sign of unfavourable conditions: Lucas 1982).

The fact that some larvae survived and developed normally over $12 \mathrm{~d}$ suggests that if starvation is common in Acanthaster planci larvae, it probably occurs at a later stage. Lucas (pers. comm.) believes that it is at the late brachiolaria stage that a shortage of food inhibits further development. This is supported by his findings (Lucas 1982) that most larvae growing on suboptimal diets managed to reach mid brachiolaria stage but few advanced to late brachiolaria.

The culturing of larvae in situ, using the submersible culture chambers, is a useful method for testing the relevancy of laboratory diets and gauging the potential for larvae to develop successfully in different habitats such as fore- or back-reefs. The latter problem will be the focus of future investigations with the submersible culture systems.

Acknowledgements. I thank J. Lucas, R. Bradbury, and P. Moran for helpful advice, G. McNaughton, P. Whyte, J. Small and $M$. Beecher for skillful craftsmanship in the designing and construction of the submersible larval culture systems, and R. McPherson, G. Mifsud, M. D. Olson, and L. Willimont for invaluable field assistance

\section{LITERATURE CITED}

Bayne, B. L. (1965). Growth and the delay of metamorphosis of the larvae of Mytilus edulis (L.). Ophelia 2: 1-47

Bayne, B. L. (1976). The biology of mussel larvae. In: Bayne, B. L. (ed.) Marine mussels; their ecology and physiology. Cambridge Univ. Press, London

Birkeland, C. (1982). Terrestrial runoff as a cause of outbreaks of Acanthaster planci (Echinodermata: Asteroidea) Mar Biol. 69: 175-185

Davis, H. C., Guillard, R. R. (1958). Relative value of ten genera of micro-organisms as food for oyster and clam larvae. Fish. Bull. U. S. Fish Wildlife Serv. 58: 293-304

Endean, R. (1982). Crown-of-thorns starfish on the Great Barrier Reef. Endeavour 6: 10-14

Gaudy, R. (1974). Feeding four species of pelagic copepods under experimental conditions. Mar. Biol. 25: 125-141

Hag, S. M. (1967). Nutritional physiology of Metridia Iucens and $M$. longa from the Gulf of Maine. Limnol. Oceanogr. 12: $40-51$

Ikeda, T., Gilmartin, M., Revelante, N., Mitchell, A. W., Carleton, J. H., Dixon, P., Hutchinson, S. M., Hing Fay, E, Boto, G. M., Iseki, K. (1980). Biological, chemical and physical observations in inshore waters of the Great Barrier Reef, North Queensland. 1975-1978. Aust. Inst. Mar. Sci., Techn. Bull., OS-80-1, Australian Institute of Marine Science, Townsville, p. 1-56

Kinne, O. (1977). Cultivation of animals: research cultivation. In: Kinne, O. (ed.) Marine ecology, Vol. HI, Cultivation, Part 2. Wiley, Chichester, p. 579-1293

Lucas, J. S. (1982). Quantitative studies of feeding and nutrition during larval development of the coral reef asteroid Acanthaster planci (L.) J. exp. mar. Biol. Ecol. 650: 173-193

Moran, P., Bradbury, R. H., Reichelt, R. E. (1985). Mesoscale studies of the crown-of-thorn/coral interaction: a case history from the Great Barrier Reef. In: Proc. of the 5th Intl. Coral Reef Symp. 2: 249

Scholander, P. F., Claff, C. L., Sveinsson, S. L., Scholander, S. I. (1952). Respiratory studies of single cells. III. Oxygen consumption during cell division. Biol. Bull. mar. biol. Lab., Woods Hole 102: 185-199

Walne, P. P. (1963). The culture of marine mollusc and crustacea. In: Orington, J. D. (ed.) The better use of the world's fauna for food. Institute of Biology, London, p. 147-175

Accepted for printing on June 3, 1985 